\title{
The well-fit for the FET model: Understanding training transfer factors in Spain
}

\author{
Carla Quesada-Pallarès
}

Universitat Autònoma de Barcelona. Spain.

carla.quesada@uab.cat

Mariel F. Musso

Centro Interdisciplinario de Investigaciones en Psicología Matemática y Experimental CONICET. Argentina. mariel.musso@hotmail.com

Anna Ciraso-Calí

Universitat de Barcelona. Spain.

anna.ciraso@ub.edu

Eduardo Cascallar

K.U. Leuven. Belgium.

cascallar@msn.com

Received: $1 / 12 / 2020$

Accepted: 15/4/2021

Published: 23/9/2021

\begin{abstract}
Learning transfer evaluation is a necessary process for practitioners to assess the effectiveness of training, and the outcomes of training produces in workers' behaviors. In this paper, we explore an alternative way to evaluate transfer: through the study of transfer facilitators and barriers. Our aim is to validate the Factors to Evaluate Transfer (FET) model in a large sample of Spanish employees using confirmatory factor analysis. We applied the Spanish version of the FET scale to a sample of 2,745 Spanish workers of public service institutions and private companies. The results show a seven-factor model as the best choice according to the adjustment indices presented in the paper. We obtained a shorter version of the instrument, with adequate construct validity as well as good reliability and internal consistency. This model is a step forward in the measurement of indirect transfer and allows keeping working on the FET model to diagnosis transfer factors and increase the probabilities of higher learning transfer levels.
\end{abstract}

Keywords: transfer factors; learning transfer; transfer evaluation; confirmatory factor analysis

Resum. El bon ajust del model FET: entendre els factors de transferència de la formació a Espanya

L'avaluació de la transferència de l'aprenentatge és un procés necessari perquè els professionals avaluïn l'eficàcia de la formació i els seus resultats en els treballadors. Aquest article explora una forma alternativa d'avaluar la transferència: a través de l'estudi de facilitadors i obstacles de la transferència. L'objectiu és validar el model FET (factors per avaluar la transferència), en una mostra de treballadors espanyols amb una anàlisi factorial confirmatòria. Es va aplicar l'escala FET en espanyol a una mostra de 2.745 treballa- 
dors espanyols de l'Administració pública i l'empresa privada. Els resultats mostren un model de set factors com la millor opció sobre la base dels índexs d'ajust presentats en l'article. Vam obtenir una versió més reduïda de l'instrument, amb una validació de constructe adequada, així com una bona fiabilitat i consistència interna. Aquest model és un pas endavant en la mesura de la transferència indirecta i permet seguir treballant en el model FET per utilitzar-lo com a diagnosi de factors de transferència i augmentar la probabilitat de nivells més alts de transferència de l'aprenentatge.

Paraules clau: factors de transferència; transferència de l'aprenentatge; avaluació de la transferència; anàlisi factorial confirmatòria

Resumen. El buen ajuste del modelo FET: comprender los factores de transferencia de la formación en España

La evaluación de la transferencia del aprendizaje es un proceso necesario para que los profesionales evalúen la eficacia de la formación y sus resultados en los trabajadores. Este artículo explora una forma alternativa de evaluar la transferencia: a través del estudio de facilitadores y obstáculos de la transferencia. Su objetivo es validar el modelo FET (factores para evaluar la transferencia), en una muestra de empleados españoles con un análisis factorial confirmatorio. Se aplicó la escala FET en español a una muestra de 2.745 trabajadores españoles de la Administración pública y la empresa privada. Los resultados muestran un modelo de siete factores como la mejor opción sobre la base de los índices de ajuste presentados en el artículo. Obtuvimos una versión más reducida del instrumento, con una validación de constructo adecuada, así como una buena fiabilidad y consistencia interna. Este modelo es un paso adelante en la medición de transferencia indirecta y permite seguir trabajando en el modelo FET para usarlo como diagnóstico de factores de transferencia y aumentar la probabilidad de mayores niveles de transferencia del aprendizaje.

Palabras clave: factores de transferencia; transferencia del aprendizaje; evaluación de la transferencia; análisis factorial confirmatorio

\begin{aligned} & \multicolumn{2}{c}{ Summary } \\ & 1. Introduction 5. Discussion \\ & 2. The FET model: 6. Conclusions \\ & theoretical background Bibliographical references \end{aligned}

3. Method

4. Results

\section{Introduction}

Evaluating learning transfer, defined as the degree to which trainees apply their learning in the work context (Baldwin \& Ford, 1988) and maintain behavior change over time (Ford et al., 2018), has been gaining importance in the last decades due to its potential to assess the results produced in a company by training transfer. However, the assessment of actual transfer has important limitations because it requires both economic and human resources. Nevertheless, there 
is an alternative way to indirectly assess learning transfer: indirect evaluation (Pineda et al., 2011) through the analysis of factors from dimensions of the work environment, trainees' characteristics, and training design (e.g., Burke \& Hutchins, 2007; Holton et al., 2000; Quesada-Pallarès \& Gegenfurtner, 2015; Fauth \& González-Martínez, 2021). When transfer barriers and facilitators are identified after training, they can be used as prediction variables to estimate whether there will be transfer or not, thus allowing the necessary steps to be taken to facilitate learning transfer. In other words, factors act as predictors, enabling an indirect measurement of transfer (Pineda \& Quesada, 2013; Quesada, 2010).

Previous studies have developed a learning transfer model for the Spanish context called Factors to Evaluate Transfer or FET (Pineda et al., 2011; Pineda-Herrero et al., 2014). The aim of this paper is to validate the FET model in a large sample of Spanish employees using confirmatory factor analysis (CFA) following the guidelines of Lloret-Segura et al. (2014). In addition, the purpose of this study is to provide evidence of construct validity for the Spanish FET scale.

\section{The FET model: theoretical background}

The FET model includes different theories related to learning transfer (for an extensive review, see Pineda-Herrero et al., 2014). It is based on Baldwin and Ford (1988) and takes into account more recent literature, which offers theoretical and empirical background. The model is composed of several theoretical constructs categorized into three dimensions: a) trainee's characteristics, b) training design, and c) the work environment. The FET considers several variables related to the trainees (dimension a): a.1) satisfaction with training; a.2) motivation to transfer; a.3) self-efficacy; and a.4) locus of control as described below.

a.1) Satisfaction with training is defined as the trainees' reaction toward the training program or activity (Kirkpatrick, 1959). Already included in Noe and Schmitt's (1986) theoretical model, satisfaction with training has been shown to be correlated with the transfer of training (i.e., Moreno, 2009; Alliger et al., 1997).

a.2) Motivation to transfer is defined as trainees' desire to apply the knowledge and skills mastered in the training program to their job (Noe \& Schmitt, 1986; Paulsen \& Kauffeld, 2017). The role of motivation in transfer is empirically unclear: in Axtell et al. (1997), motivation to transfer was a significant predictor of transfer, even one year later $(\beta=.48, p<.01)$, while other studies (Burkolter et al., 2009; Wolfe et al., 1998) claim that relationships between motivation and transfer are weak. As Reinold et al. (2018) state, this unclear role may be because motivation to transfer acts as a mediating variable between the social support dimension and training transfer. 
a.3) Self-efficacy is defined as the "conviction that one can successfully execute the behavior required to produce the outcomes" (Bandura, 1977, p. 193). Many researchers have demonstrated that self-efficacy is correlated with the application, generalization, and maintenance of learning (Yamkovenko et al., 2007; Chiaburu \& Marinova, 2005; Gaudine \& Saks, 2004; Machin \& Fogarty, 2004; Iqbal \& Dastgeer, 2017).

a.4) Locus of control is defined as "the extent to which the individual is apt to make internal or external attributions regarding work outcomes" (Noe \& Schmitt, 1986, p. 501). The meta-analysis of Colquitt et al. (2000) pointed out the relationships between locus of control and transfer $(\beta=.41, p<.05)$.

From the viewpoint of the training itself (dimension b), the FET model includes: b.1) transfer design, and b.2) orientation toward job requirements.

b.1) Transfer design groups those elements of training design oriented to its real applicability. Different methods and strategies are included in this concept, such as near transfer (Holladay \& Quiñones, 2003) and training activities that provide examples of different ways to use learning in the job context (Velada et al., 2007).

b.2) Orientation towards job requirements is defined as the trainees' perception that training responds to their professional needs related to the workplace. Several studies (Taylor et al., 2005; Ruona et al., 2002; Axtell et al., 1997) have found that there is a bond between training content and job needs, such as Liam and Morris $(2006, p<.01, r=.338)$. This aspect may also be related to the selection of qualified trainees to attend training and the attendance framed as an opportunity, as pointed out by Hughes et al. (2018).

Finally, as regards the work environment (dimension c), the FET considers four variables: c.1) manager's support to transfer; c.2) peers' support to transfer; c.3) accountability; and c.4) lack of possibilities to transfer.

c.1) Manager's support to transfer is defined as managers' strategies to facilitate transfer and the material and emotional support that they can give to the trainees (Smith-Jentsch et al., 2001; Van der Klink et al., 2001; Salas et al., 1999).

c.2) Peers' support to transfer is defined as the degree to which co-workers support the use of new knowledge at the workplace (Chiaburu \& Marinova, 2005; Hawley \& Barnard, 2005; Xiao, 1996). Support from co-workers was found to be the strongest predictor of motivation to transfer (Reinold et al., 2018).

c.3) Accountability is defined as the degree to which learners are expected to use on-the-job knowledge and skills for which they were trained by the organization, culture, and/or management; and their perceived responsi- 


\section{Figure 1. Hypothesized FET model}

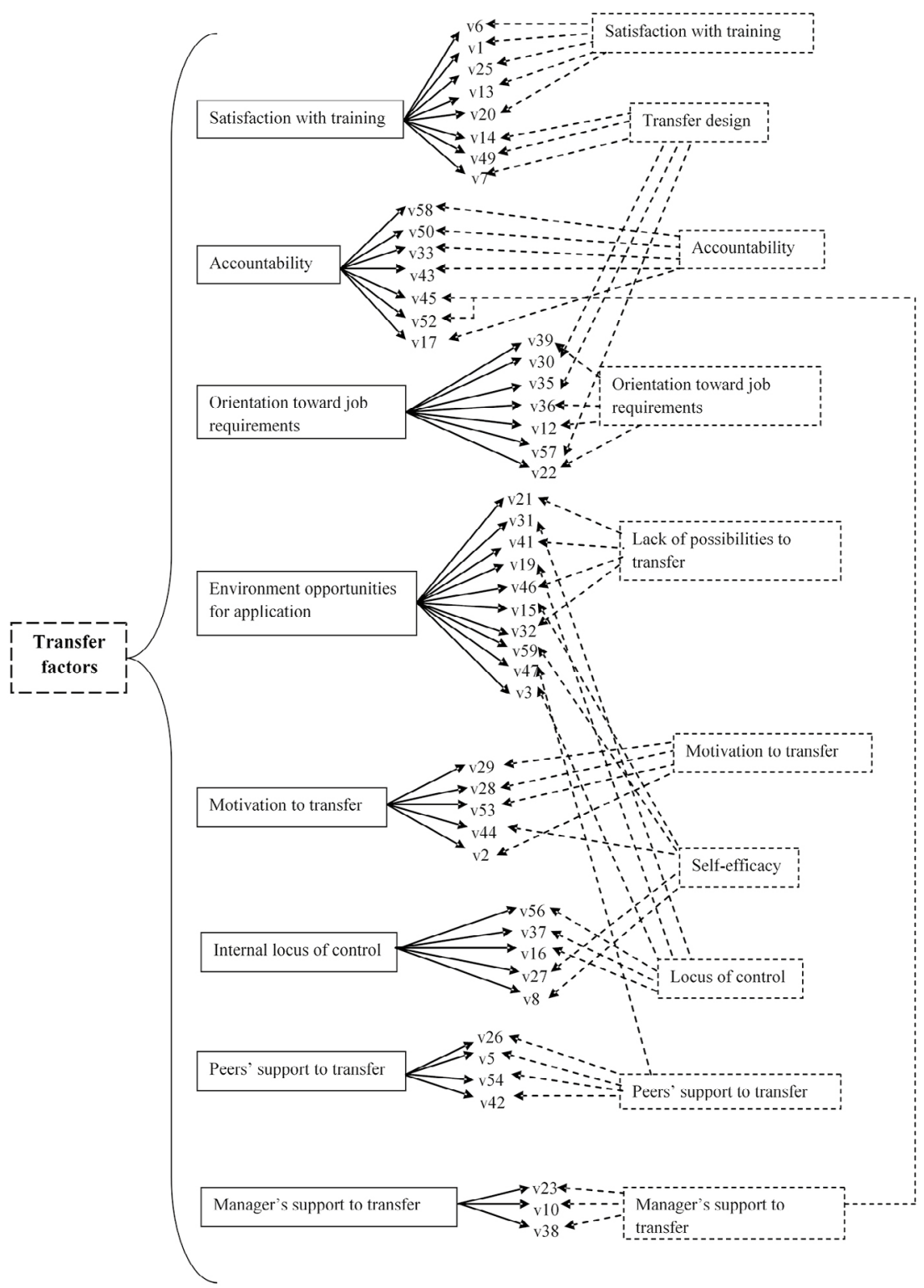

Note: Dashed arrows represent item origin, while continuous arrows represent item destination.

Source: Based on the model of Pineda-Herrero et al. (2014). 
bility to use it (Kontoghiorghes, 2001; Brinkerhoff \& Montesino, 1995; Yarnold et al., 1988). In previous studies (Pineda \& Quesada, 2013), accountability showed a significant impact on transfer $(\beta=.048, p<.05)$. However, it can still be deficient at both the practitioners' and the research level (Tews \& Burke-Smalley, 2017).

c.4) Lack of possibilities to transfer is defined as the absence of situations to practice new learning, and the lack of necessary resources to do so (Lim \& Morris, 2006; Gaudine \& Saks, 2004; Brinkerhoff \& Montesino, 1995).

Pineda et al. (2011) initially explored the factor structure of the FET model by exploratory factor analysis (EFA) using a maximum likelihood method and promax rotation. The authors found an eight-factor model that explained $50.73 \%$ of the variance (Pineda-Herrero et al., 2014). However, new studies are needed to confirm these findings. The present study hypothesizes that the validated FET model presents the same structure as the theoretical model (see Figure 1) and shows an appropriate fit to the data.

\section{Method}

\subsection{Participants}

This study involved a total non-probabilistic sample of 2,745 trainees from Spanish private organizations $(85.1 \%)$, public organizations $(14.5 \%)$, and NGOs $(0.4 \%)$. The sample included trainees of both genders (female $=50.8 \%)$ aged 17 to 79 years old $(M=38.61 ; S D=9.52)$. Table 1 shows the distribution of the surveyed trainees according to profile variables.

Table 1. Distribution of the surveyed trainees according to profile variables

\begin{tabular}{ll}
\hline Profile variables & Trainees' distribution \\
\hline Sex & Male: $49.2 \%$ \\
& Female: $50.8 \%$ \\
\hline Age & Mean: $38.61(S D=9.52)$ \\
\hline Job Position & Manager: $3.6 \%$ \\
& Middle manager: $21.1 \%$ \\
& Technician: $22.8 \%$ \\
& Skilled worker: $45.4 \%$ \\
& Unskilled worker: $7.2 \%$ \\
Training Content & Technical: $52.8 \%$ \\
& Legal: $4.6 \%$ \\
& Social skills: $8 \%$ \\
& Management: $15.2 \%$ \\
& Risk prevention: $10.5 \%$ \\
\hline
\end{tabular}

Source: Own elaboration. 
The typical length of training ranged from 12 to 40 hours; $54.4 \%$ of the sample participated in face-to-face training and $45.6 \%$ attended eLearning training activities.

\subsection{Instruments}

We used a self-report measure, which included subsets of items to evaluate each construct. This instrument included 49 items with a 5-point Likert scale $(1=$ completely disagree, 5 = completely agree $)$ that measured the eight factors presented above.

\subsection{Procedure}

The FET instrument was applied just before finishing the training in the last 30 minutes using a paper-and-pencil format. All data were gathered in a timeframe of three months. The study was designed as longitudinal and a deferred scale three months was applied after the training finished to measure learning transfer. However, the present article only uses the data collected with the FET instrument, which measure learning transfer factors.

\subsection{Statistical and psychometric analysis}

EFA using the maximum likelihood extraction method (Lloret-Segura et al., 2014) with promax rotation was carried out to explore the factor structure of the instrument in a randomized subsample of 1,364 participants from the original sample. The analysis excluded missing values, which occurred in 27 participants. Firstly, we calculated the Kaiser-Meyer-Olkin (KMO) measure of sampling adequacy and Bartlett's test of sphericity to determine the applicability of the EFA. We used the Scree Plot criterion to identify the number of factors. Factor loadings above .40 were considered to select the items corresponding to each factor.

Secondly, the structure validity of the explored solution and a theoretical eight-factor model were examined using CFA in another sub-sample $(n=1,381)$, following the guidelines of Lloret-Segura et al. (2014). Missing values were replaced by the means. The goodness-of-fit level of the models was considered using the chi-square $(\chi 2)$ test and the comparative fit index (CFI) and normed fit index (NFI). In addition, we calculated the root mean square error of approximation (RMSEA) for both models to identify their degrees of error. A normality test on the sample revealed no symmetry problems; it means that no corrections were needed. Also, estimation problems were analyzed and proved to be non-significant. 


\section{Results}

Kaiser-Meyer-Olkin $(\mathrm{KMO}=.939)$ and the significance of the Bartlett test $(20133.901 ; p<.001)$ suggested that the factor analysis was appropriate. According to the Scree Plot criterion, seven factors explaining $48.9 \%$ of the variance were retained. Only items with factor loadings above .40 were included. Therefore, 10 items were excluded (items 2, 4, 6, 7, 14, 22, 32, 35, 41, and 45) because they were complex and/or their factor loading was less than .40 .

This factor structure was tested with CFA and compared with an eightfactor model provided by the literature. Table 2 shows the model fit indices for each model.

Table 2. Fit indices for FET Models

\begin{tabular}{lccccccccc}
\hline Models & $\chi 2$ & df & $\mathbf{p}$ & CFI & NFI & RMSEA & $\Delta \chi 2 \mathrm{a}$ & $\Delta$ df & $\begin{array}{c}\text { estimated } \\
\text { parameters }\end{array}$ \\
\hline $\begin{array}{l}\text { Sample } \\
(n=1,381)\end{array}$ & & & & & & & & & \\
$\begin{array}{l}\text { FET } \\
\text { model 7F }\end{array}$ & 2525.4 & 679 & .001 & .92 & .89 & .044 & & & 140 \\
$\begin{array}{l}\text { FET } \\
\text { model 8F }\end{array}$ & 4409.6 & 1052 & .001 & .89 & .86 & .048 & 1884.2 & 373 & 172 \\
\hline
\end{tabular}

Note: ${ }^{a}$ Comparison to the 7F Model. Values higher than .90 for CIF and NFI and RMSEA below .05 indicate a good fit. $\chi^{2}$ difference tests indicated that the $8 \mathrm{~F}$ model provided a significantly worse fit than the sevenfactor model. The model with the best fit is shown in bold.

Source: Own elaboration.

The first indices observed were the absolute or stand-alone indices, which "measure the discrepancy between the observed sample matrix and that implied by the CFA model being tested" (Hancock et al., 2018, p. 109). The chi-square was significant in all models, indicating that we can reject the null hypothesis (the theoretical model fits the empirical data); nonetheless, the chi-square test is very sensitive to sample sizes. Therefore, if we follow the chi-square criterion of lesser value, the seven-factor model shows the best fit $\left(\chi^{2}=2525.497, d f=679, p<.001\right)$.

We also considered parsimony-adjusted indices, which "measure the discrepancy between the observed and implied matrices, but incorporate some type of penalty for model complexity" (Hancock et al., 2018, p. 110). The RMSEA values indicated that all models have a low error (less than 0.50 ), so they have an acceptable fit.

In addition, we analyzed the incremental fit indices, which "measure the fit of the model of interest relative to the fit of a null or baseline model" (Hancock et al., 2018, p. 110). We used CFI and NFI for this purpose and the seven-factor model showed the highest values of both indices at an acceptable moderate level.

From the evaluation of all fit indices, the findings showed that the sevenfactor model displayed a better fit to the empirical data than the eight-factor 
model, namely better absolute indices, lower parsimony-adjusted indices, and higher incremental fit indices.

Reliability analyses of the best-adjusted model (see Table 3) showed satisfactory coefficients for all the factors following the criteria of Nunnally (1978), that is, the analyzed scales are reliable by themselves and have good internal consistency.

Table 3. Cronbach's coefficient for the eight factors (Model C)

\begin{tabular}{lcc}
\hline Factors & Cronbach's $\alpha$ value & Number of items \\
\hline Satisfaction with training & .881 & 6 \\
Environment possibilities for application & .835 & 10 \\
\hline Orientation towards job requirements & .857 & 7 \\
\hline Accountability & .854 & 6 \\
\hline Motivation to transfer & .815 & 4 \\
\hline Internal locus of control & .710 & 3 \\
\hline Manager's and peers' support to transfer & .735 & 3 \\
\hline
\end{tabular}

Source: Own elaboration.

Table 4 presents some examples of items to better understand the final factors. Table 5 shows items loadings to the factors (pattern matrix) and Table 6 provides information about the factor correlation matrix of the selected seven-factor model.

Table 4. Examples of items for each final factor

\begin{tabular}{|c|c|}
\hline Factors & Item examples \\
\hline Satisfaction with training & $\begin{array}{l}\text { The training activity was interesting. } \\
\text { The trainer did a good job. }\end{array}$ \\
\hline $\begin{array}{l}\text { Environment opportunities for } \\
\text { application }\end{array}$ & $\begin{array}{l}\text { My daily workload does not allow me to apply the training in } \\
\text { my workplace. } \\
\text { I do not have the resources I need to apply the training. }\end{array}$ \\
\hline $\begin{array}{l}\text { Orientation towards job require- } \\
\text { ments }\end{array}$ & $\begin{array}{l}\text { The exercises we did during training were similar to the } \\
\text { tasks I perform in my workplace. } \\
\text { During the training, examples related to my work reality } \\
\text { were provided. }\end{array}$ \\
\hline Accountability & $\begin{array}{l}\text { My boss asks me for evidence of what I applied from the } \\
\text { training. } \\
\text { After the training, I explained to my boss the changes I intro- } \\
\text { duced in my workplace. }\end{array}$ \\
\hline Motivation to transfer & $\begin{array}{l}\text { I am usually willing to practice what I learned in the training. } \\
\text { I would like the training to help me improve my job. }\end{array}$ \\
\hline Internal locus of control & $\begin{array}{l}\text { My success in applying training is up to me. } \\
\text { After training, I feel confident that I can successfully apply } \\
\text { what I have learned. }\end{array}$ \\
\hline
\end{tabular}




\begin{tabular}{ll}
\hline Factors & Item examples \\
\hline Manager's and peers' support to & My boss encourages me to introduce changes based on \\
transfer & what I learned during training. \\
& My boss facilitates the application of learning to my work- \\
& place. \\
& When I apply training in my workplace, I count on peers to \\
& help. \\
& My peers facilitate the application of changes in my work- \\
place based on the training.
\end{tabular}

Note: Original items were in Spanish and this article provides an English translation with no translationvalidation process.

Source: Own elaboration.

Table 5. Factor loadings of the seven-factors model (pattern matrix)

\begin{tabular}{|c|c|c|c|c|c|c|c|}
\hline Items & Sf & Poent & Orinec & Rencu & MotiT & LoCon & Support_T \\
\hline i5 & .873 & & & & & & \\
\hline i1 & .856 & & & & & & \\
\hline i10 & .789 & & & & & & \\
\hline $\mathrm{i} 20$ & .718 & & & & & & \\
\hline i16 & .640 & & & & & & \\
\hline $\mathrm{i} 11$ & .474 & & & & & & \\
\hline i17 & & .682 & & & & & \\
\hline i34 & & .643 & & & & & \\
\hline i26 & & .609 & & & & & \\
\hline $\mathrm{i} 12$ & & .600 & & & & & \\
\hline i15 & & .598 & & & & & \\
\hline i3 & & .575 & & & & & \\
\hline $\mathrm{i} 27$ & & .568 & & & & & \\
\hline i49 & & .543 & & & & & \\
\hline i39 & & .541 & & & & & \\
\hline $\mathrm{i} 40$ & & .524 & & & & & \\
\hline $\mathrm{i} 25$ & & & .805 & & & & \\
\hline i30 & & & .703 & & & & \\
\hline i33 & & & .677 & & & & \\
\hline i29 & & & .621 & & & & \\
\hline i18 & & & .619 & & & & \\
\hline i9 & & & .589 & & & & \\
\hline $\mathrm{i} 47$ & & & .555 & & & & \\
\hline ¡42 & & & & .818 & & & \\
\hline
\end{tabular}




\begin{tabular}{|c|c|c|c|c|c|c|c|}
\hline Items & Sf & Poent & Orinec & Rencu & MotiT & LoCon & Support_T \\
\hline $\mathrm{i} 48$ & & & & .807 & & & \\
\hline $\mathrm{i} 28$ & & & & .712 & & & \\
\hline i36 & & & & .655 & & & \\
\hline i38 & & & & .548 & & & \\
\hline $\mathrm{i} 43$ & & & & .415 & & & \\
\hline i24 & & & & & .870 & & \\
\hline i44 & & & & & .632 & & \\
\hline $\mathrm{i} 23$ & & & & & .628 & & \\
\hline i37 & & & & & .471 & & \\
\hline i46 & & & & & & .729 & \\
\hline i13 & & & & & & .720 & \\
\hline i31 & & & & & & .583 & \\
\hline i8 & & & & & & & .688 \\
\hline ¡19 & & & & & & & .617 \\
\hline 121 & & & & & & & .495 \\
\hline$\%$ Variance & 25.227 & 8.640 & 6.956 & 2.973 & 1.852 & 1.783 & 1.527 \\
\hline$\%$ Cumulative & 25.227 & 33.867 & 40.823 & 43.796 & 45.648 & 47.431 & 48.958 \\
\hline
\end{tabular}

Note: Extraction method: maximum likelihood. Rotation method: promax with Kaiser normalization. aRotation converged in 7 iterations.; Sf: Satisfaction with training; Poent: Environment opportunities for application; Orinec: Orientation toward job requirements; Rencu: Accountability; MotiT: Motivation to transfer; LoCon: Internal locus of control. Support_T: Manager's and peers' support to transfer

Source: Own elaboration.

Table 6. Factor correlation matrix

\begin{tabular}{cccccccc}
\hline Factor & $\mathbf{1}$ & $\mathbf{2}$ & $\mathbf{3}$ & $\mathbf{4}$ & $\mathbf{5}$ & $\mathbf{6}$ & $\mathbf{7}$ \\
\hline 1 & 1.000 & .222 & .589 & .184 & .587 & .473 & .390 \\
2 & .222 & 1.000 & .234 & -.067 & .333 & .286 & .281 \\
3 & .589 & .234 & 1.000 & .450 & .696 & .629 & .582 \\
4 & .184 & -.067 & .450 & 1.000 & .345 & .358 & .511 \\
5 & .587 & .333 & .696 & .345 & 1.000 & .556 & .524 \\
\hline 6 & .473 & .286 & .629 & .358 & .556 & 1.000 & .463 \\
7 & .390 & .281 & .582 & .511 & .524 & .463 & 1.000 \\
\hline
\end{tabular}

Note: Extraction method: maximum likelihood. Rotation method: promax with Kaiser mormalization.

Source: Own elaboration.

The first factor, satisfaction with training, refers to trainees' reactions toward the training program and the teaching process. The second factor involves items related to environment possibilities for application, that is, the existence of situations to put into practice new learning, and the fact that 
Figure 2. Path diagram of seven-factor model from the CFA

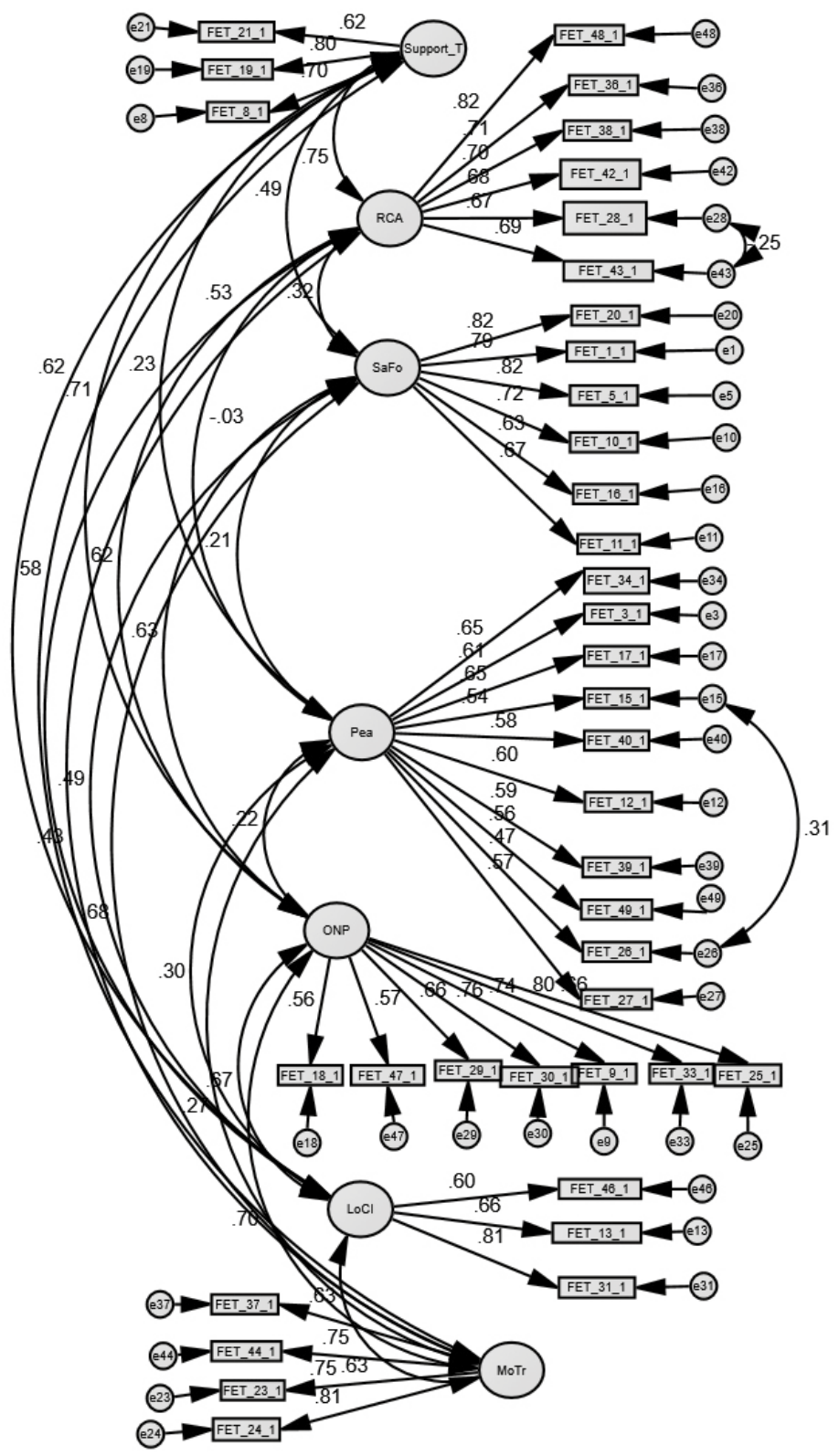

Note: Support_T = Manager's and peers' support to transfer; Sf: Satisfaction with training; Rencu: Accountability; Orinec: Orientation toward job requirements; Poent: Environment opportunities for application; MotiT: Motivation to transfer; LoCon: Internal locus of control.

Source: Own elaboration. 
trainees can access the needed resources. The third factor, orientation toward job requirements, is related to trainees' perception that training responds to their professional needs related to the workplace and whether the training is related closely enough to the reality of their workplace. The fourth factor, accountability, involves items regarding the extent to which the boss expects the trainees to use knowledge and skills in their job, including their perceived responsibility to do so. Motivation to transfer-related items weighted on another factor: trainees' willingness to put into practice in the workplace the knowledge and skills learned in the training program. The sixth factor refers to the internal locus of control. This factor refers to the extent to which the individual is able to make internal attributions regarding work outcomes, that is, that a trainee thinks that $s /$ he is the only person responsible for the success in the transfer process. Finally, the last factor involved items related to the manager's and peers' support to transfer, namely manager's or peers' strategies to facilitate transfer, as well as the material and emotional support that they can give to the trainees.

\section{Discussion}

The purpose of this study was to validate the FET model in a large sample of Spanish employees. This is the first study that has tested the factorial structure of the FET model using CFA. Firstly, it was necessary to explore the factorial structure using an EFA, and a new solution with seven factors was obtained, unlike the eight dimensions of the original validation. The comparison of both the new and theoretical models using CFA indicates a good fit for the sevenfactor solution, this indicating that our hypothesis is partially confirmed. This model included only 39 items and excluded some complex items (those that have a similar path coefficient in more than one factor) and items with very low path coefficients.

Due to the removal of some items, the resulting distribution of items into factors is somewhat different compared to the initially hypothesized model, as there is a change from an eight-factor solution to a seven-factor solution. Indeed, there are some differences between the theoretical constructs and the factors which emerged from the analyses, which are worthy of discussion. First, the variable transfer design did not appear as a factor; and its items split into the factors orientation toward job requirements and satisfaction with training. For this reason, the final definition of these factors includes some elements related to the trainer performance and training design. Second, another important difference is the loss of the self-efficacy factor in the final seven-factor FET model. Two of its items were removed; and the remaining three, joined with motivation, internal locus of control, and environment possibilities for application. Thirdly, two factors related to environmental support converged into one, with no differentiation between the support from trainees' managers and their peers. Consequently, the new adjusted model requires a new interpretation taking into account the theoretical framework. 
The loss of three of the initial factors in the validation process confirms the need to continue research in this area to understand the possible reasons for these differences. Clearly, more research is needed to explore the theoretical definition of the variable transfer design and to build a solid and comprehensive model of variables in this dimension (Pineda \& Quesada, 2013; Velada et al., 2007; Kodwani \& Prashar, 2021). However, it would be worthy to explore if this factor entails difficulties to validate it with people not familiar with pedagogical concepts or if it also affects teachers or trainers.

On the other hand, the way that the self-efficacy items moved to other factors suggests that trainees' responses may be following Bandura's (1977) distinction between efficacy-expectations and outcome-expectations. Consequently, it may be interesting to study the behavior of these two aspects together with the resulting transfer factors, as Bourne et al. (2021) have pointed out.

Moreover, the final composition of the factor manager's and peers' support to transfer, which includes two items related to manager's support and only one item regarding peers' support, is consistent with previous findings. For example, some authors have highlighted the possibility of combining these two sources of support into a single factor (Festner \& Gruber, 2008; Roig et al., 2019), whereas other authors, such as Froehlich and Gegenfurtner (2019), have suggested that the correct way to approach this factor should be to focus on what kind of support trainees receive to transfer (i.e., informal, feedback or instances of help) rather than from whom it is received (i.e., supervisors or peers). In future applications of the FET model, we could explore this last approach to the factor, which would allow us to examine more horizontal organizations in which supervisors do not act differently from peers, or really vertical-type organizations in which supervisors are not familiar with the specific actions of their subordinates (Hua, 2013).

Nonetheless, not being able to differentiate between manager's and peers' support to transfer is a limitation of our result. Some studies found that peer support was the strongest predictor of transfer motivation (Reinhold et al., 2018) and on training transfer (Hue, 2013); while others found that supervisor is key to predict training transfer (Dewayani \& Ferdinand, 2019). On the other hand, the sample was only representative of the population of Spanish workers and surely more research is needed to check if the model is valid and reliable for training in other contexts and learning environments, such as online training (Martins et al., 2019).

\section{Conclusions}

The results of this study have provided evidence in support of a learning transfer model consisting of seven factors for Spanish employees. Specifically, we obtained a shorter version of the instrument with adequate construct validity, as well as good reliability and internal consistency which were tested both through EFA and CFA analyses. Future research is necessary to test this model in another Spanish sample considering the invariance of the model in different 
organizational contexts as well as in other countries in which Spanish is the main language. In addition, further studies should analyze the predictive validity of effective training transfer in the workplace.

The resultant FET model is a step forward in the field of research on learning transfer factors, because there are no models that include factors of different perspectives in the Spanish context. This model can provide a lot of information to organizations to improve their training and hence their impact on the market.

\section{Bibliographical references}

Alliger, G. M., Tannenbaum, S. I., Bennett Jr., W, Traver, H., \& Schotland, A. (1997). A meta-analysis of the relations among training criteria. Personnel Psychology, $50(2), 341-358$. $<$ http://dx.doi.org/10.1111/j.1744-6570.1997.tb00911.x>

Axtell, C. M., Maitlis, S., \& Yearta, S. K. (1997). Predicting immediate and longer-term transfer. Personnel Review, 26(3), 201-213. $<$ http://dx.doi.org/10.1108/00483489710161413>

Baldwin, T. T., \& Ford, J. K. (1988). Transfer of training: A review and directions for future research. Personnel Psychology, 41(1), 63-105. <http://dx.doi.org/10.1111/j.1744-6570.1988.tb00632.x>

BANDURA, A. (1977). Self-efficacy: Towards a unifying theory of behavioral change. Psychological Review, 84(2), 191-215. <http://dx.doi.org/10.1037//0033-295X.84.2.191>

Brinkerhoff, R. O., \& Montesino, M. U. (1995). Partnerships for training transfer: Lessons from a corporate study. Human Resource Development Quarterly, 6(3), 263-274. <http://dx.doi.org/10.1002/hrdq.3920060305>

Bourne, M. J., Smeltzer, S. C., \& Kelly, M. M. (2021). Clinical teacher self-efficacy: A concept analysis. Nurse Education in Practice, 52(103029), 1-8. <https://doi.org/10.1016/j.nepr.2021.103029>

Burke, L. A., \& HuTchins, H. M. (2007). Training transfer: An integrative literature review. Human Resource Development Review, 6, 263-296. $<$ http://dx.doi.org/10.1177/1534484307303035>

Burkolter, D., Kluge, A., Sauer, J., \& Ritzmann, S. (2009). The predictive qualities of operator characteristics for profess control performance: The influence of personality and cognitive variables. Ergonomics, 52, 302-311. <http://dx.doi.org/10.1080/00140130802376067>

Chiaburu, D. S., \& Marinova, S. V. (2005). What predicts skill transfer? An exploratory study of goal orientation, training self-efficacy, and organizational supports. International Journal of Training and Development, 9(2), 110-123. $<$ http://dx.doi.org/10.1111/j.1468-2419.2005.00225.x>

Colquitt, J. A., LePine, J. A., \& Noe, R. A. (2000). Toward an integrative theory of training motivation: A meta-analytic path analysis of 20 years of research. Journal of Applied Psychology, 85(5), 678-707. <http://dx.doi.org/10.1037//0021-9010.85.5.678>

Dewayani, J., \& Ferdinand, A. (2019). Motivation to transfer, supervisor support, proactive learning, and training transfer: Testing interaction effects. International Journal of Economics and Business Administration, 7(3), 141-150. $<$ https://doi.org/10.35808/ijeba/314> 
Fauth, F., \& González-Martínez, J. (2021). On the concept of learning transfer for continuous and online training: A literature review. Education Sciences, 11(133), 1-13. <https://doi.org/10.3390/educsci11030133>

Festner, D., \& Gruber, H. (2008). Conditions of work environments in fostering transfer of training (Research Report No. 36). University of Regensburg, Dept. Prof. Hans Gruber. <https://doi.org/10.1163/9789087906450_015>

Ford, J. K., Baldwin, T. T., \& Prasad, J. (2018). Transfer of training: The known and the unknown. Annual Review of Organizational Psychology and Organizational Behavior, 5, 201-225. <https://doi.org/10.1146/annurev-orgpsych-032117-104443>

Froehlich, D. E., \& Gegenfurtner, A. (2019). Social support in transitioning from training to the workplace: A social network perspective. In H. FAsCHING (Ed.). Beziehungen in pädagogischen arbeitsfeldern und ihren transitionen über die lebensalter (pp. 208-222). Verlag Julius Klinkhardt. Retrieved from <https://bit. ly/2oYOT0o $>$.

Gaudine, A. P., \& Saks, A. M. (2004). A longitudinal quasi-experiment on the effects of posttraining transfer interventions. Human Resource Development Quarterly, 15(1), 57-76. $<$ http://dx.doi.org/10.1002/hrdq.1087>

Hancock, G. R., Stapleton, L., \& Mueller, R. O. (2018). The reviewer's guide to quantitative methods in the social sciences (2nd ed.). London: Routledge. <https://doi.org/10.4324/9781315755649>

Hawley, J. D., \& Barnard, J. K. (2005). Work environment characteristics and implications for training transfer: A case study of the nuclear power industry. Human Resource Development International, 8(1), 65-80. <http://dx.doi.org/10.1080/1367886042000338308>

Holladay, C. L., \& Quiñones, M. A. (2003). Practice variability and transfer of training: The role of self-efficacy generality. Journal of Applied Psychology, 88(6), 1094-1103. <http://dx.doi.org/10.1037/0021-9010.88.6.1094>

Holton, E. F., Bates, R. A., \& Ruona, W. E. A. (2000). Development of a generalized learning transfer system inventory. Human Resource Development Quarterly, 11(4), 333-360. $<$ http://dx.doi.org/10.1002/1532-1096(200024)11:4<333::AID-HRDQ2>3.0.CO;2-P>

Hua, N. G. (2013). The influence of supervisory and peer support on the transfer of training. Studies in Business \& Economics, 8(3), 82-97.

Hughes, A. M., Zajac, S., Spencer, J. M., \& Salas, E. (2018). A checklist for facilitating training transfer in organizations. Journal of Training and Development, 22(4), 334-345. <http://dx.doi.org/10.1111/ijtd.12141>

IQBAL, K., \& DASTGEeR, G. (2017). Impact of self-efficacy and retention on transfer of training: The mediating role of motivation to transfer. Journal of Management Development, 36(10), 1270-1282. <https://doi.org/10.1108/JMD-06-2015-0087>

KirkPATRICK, D. L. (1959). Techniques for evaluating training programs. Journal of American Society for Training and Development, 11, 1-13.

Kodwani, A. D., \& Prashar, S. (2021). Influence of individual characteristics, training design and environmental factors on training transfer: A study using 
hierarchical regression. Evidence-based HRM, Vol. ahead-of-print (No. ahead-ofprint).

<https://doi.org/10.1108/EBHRM-09-2019-0085>

Kontoghiorghes, C. (2001). Factors affecting training effectiveness in the context of the introduction of new technology: A US case study. International Journal of Training and Development, 5, 248-260. $<$ http://dx.doi.org/10.1111/1468-2419.00137>

Lim, D. H., \& Morris, M. L. (2006). Influence of trainee characteristics, instructional satisfaction, and organizational climate on perceived learning and training transfer. Human Resource Development Quarterly, 17(1), 85-115. $<$ http://dx.doi.org/10.1002/hrdq.1162>

Lloret-Segura, S., Ferreres-Traver, A., Hernández-Baeza, A., \& Tomás-Marco, I. (2014). El análisis factorial exploratorio de los ítems: una guía práctica, revisada $\mathrm{y}$ actualizada [Exploratory factor analysis of items: A practical guide, revised and updated]. Anales de psicología, 30(3), 1151-1169. $<$ http://dx.doi.org/10.6018/analesps.30.3.199361>

Machin, M. A., \& Fogarty, G. J. (2003). Perceptions of training - related factors and personal variables as predictors of transfer implementation intentions. Journal of Business and Psychology, 18(1), 51-71. $<$ http://dx.doi.org/10.1023/A:1025082920860>

Martins, L. B., Zerbini, T., \& Medina, F. J. (2019). Impact of online training on behavioral transfer and job performance in a large organization. Journal of Work and Organizational Psychology, 35(1), 27-37. $<$ https://doi.org/10.5093/jwop2019a4>

Moreno, M. V. (2009). Avaluació de la transferència de la formació contínua per a directius/ves de l'administració Pública de Catalunya: Creació, aplicación $i$ anàlisi d'un model d'avaluació de la transferencia [Evaluation of the transfer of continuous training for managers of the public administration of Catalonia: Creation, application and analysis of a transfer evaluation model]. $\mathrm{PhD}$ thesis, Universitat Autónoma de Barcelona.

Noe, R. A., \& Schmitt, N. (1986). The influence of trainee attitudes on training effectiveness: Test of a model. Personnel Psychology, 39, 497-523. $<$ http://dx.doi.org/10.1111/j.1744-6570.1986.tb00950.x>

Nunnally, J. C. (1978). Psychometric theory. New York: McGraw-Hill.

Paulsen, H. F. K., \& Kauffeld, S. (2017). Linking positive affect and motivation to transfer within training: A multilevel study. International Journal of Training and Development, 21(1), 35-52. $<$ http://dx.doi.org/10.1111/ijtd.12090>

Pineda, P., \& Quesada, C. (2013). Evaluación de la transferencia de la formación continua mediante el modelo ETF de factores [Evaluation of the transfer of continuing education using the FET factors model]. Revista Iberoamericana de Educación, 61(1), 1-11. <https://doi.org/10.35362/rie6111273>

Pineda, P., Quesada, C., \& Ciraso, A. (2011). Evaluating training effectiveness: Results of the FET model in the public administration in Spain. 7th International Conference on Researching Work and Learning. Shanghai: Normal University of China.

Pineda-Herrero, P., Quesada-Pallarès, C., \& Ciraso-Calí, A. (2014). Evaluation of training transfer factors: The FET model. In K. SchNeIder (Ed.). Trans- 
fer of learning in organizations (pp. 121-144). Cham: Springer International Publishing. <https://doi.org/10.1007/978-3-319-02093-8_8>

QUESADA, C. (2010). Creating a model for evaluating the effectiveness of training in the public administration of Catalonia (Doctoral Workshop). 11th International Conference on Human Resource Development: Human Resource Development in the Era of Global Mobility. Pécs: University of Pécs.

Quesada-Pallarès, C., \& Gegenfurtner, A. (2015). Toward a unified model of motivation for training transfer: A phase perspective. Zeitschrift für Erziehungswissenschaft, 18(1), 107-121. <https://doi.org/10.1007/978-3-658-06616-1_7>

Reinhold, S., Gegenfurtner, A., \& Lewalter, D. (2018). Social support and motivation to transfer as predictors of training transfer: Testing full and partial mediation using meta-analytic structural equation modelling. International Journal of Training and Development, 22(1), 1-14. $<\mathrm{http}: / /$ dx.doi.org/10.1111/ijtd.12115>

Roig, H., Quesada-Pallarès, C., \& Pineda-Herrero, P. (2019). Diseño y pilotaje del METEnf: Modelo de evaluación de los factores de transferencia de la formación de los nuevos profesionales en Enfermería [Design and piloting of the METEnf: Model for the evaluation of transfer factors in the training of new professionals in nursing. Educación Médica, 26, 1-6. <https://doi.org/10.1016/j.edumed.2019.09.005>

Ruona, W. E. A., Leimbach, M., Holton, E. F. III, \& Bates, R. (2002). The relationship between learner utility reactions and predicted learning transfer among trainees. International Journal of Training and Development, 6(4), 218-228. $<$ http://dx.doi.org/10.1111/1468-2419.00160>

Salas, E., Rozell, D., Mullen, B., \& Driskell, J. E. (1999). The effect of team building on performance: An integration. Small Group Research, 30(3), 309329. <http://dx.doi.org/10.1177/104649649903000303>

Smith-Jentsch, K. A., Salas, E., \& Brannick, M. T. (2001). To transfer or not to transfer? Investigating the combined effects of trainee characteristics, team leader support, and team climate. Journal of Applied Psychology, 86(2), 279-292. $<$ https://doi.org/10.1037/0021-9010.86.2.279>

TaYlor, P., Russ-EFT, D., \& CHAN, D. (2005). The effectiveness of behavior modeling training across settings and features of study design. Journal of Applied Psychology, 90, 692-709. <https://doi.org/10.1037/0021-9010.90.4.692>

Tews, M. J., \& BurKe-Smalley, L. A. (2017). Enhancing training transfer by promoting accountability in different work contexts. In K. BRown (Ed.). The Cambridge handbook of workplace training and employee development (pp. 201-227). Cambridge University Press. $<$ https://doi.org/10.1017/9781316091067.011>

VAn Der Klink, M., Gielen, E., \& NaUta, C. (2001). Supervisory support as a major condition to enhance transfer. International Journal of Training and Development, 5(1), 52-63. <http://dx.doi.org/10.1111/1468-2419.00121>

Velada, R., Caetano, A., Michel, J. W., Lyons, B. D., \& Kavanagh, M.J. (2007). The effects of training design, individual characteristics and work environment 
on transfer of training. International Journal of Training and Development, 11(4), 282-294.

<http://dx.doi.org/10.1111/j.1468-2419.2007.00286.x>

Wolfe, S. L., Nordstrom, C. R., \& Williams, K. B. (1998). The effect of enhancing self-efficacy prior to job training. Journal of Social Behavior and Personality, 13, 633-650.

XIAO, J. (1996). The relationship between organizational factors and the transfer of training in the electronics industry in Shenzchen, China. Human Resource Development Quarterly, 7, 55-73. $<$ http://dx.doi.org/10.1002/hrdq.3920070107>

Yamkovenko, B. V., Holton, E. F., \& Bates, R.A. (2007). The learning transfer system inventory (LTSI) in Ukraine: The cross-cultural validation of the instrument. Journal of European Industrial Training, 31(5), 377-401. $<$ https://doi.org/10.1108/03090590710756819>

Yarnold, P. R., Mueser, K. T., \& Lyons, J. S. (1988). Type A behaviour, accountability, and work rate in small groups. Journal of Research in Personality, 22(3), 353-360. $<$ http://dx.doi.org/10.1016/0092-6566(88)90035-9> 